\title{
PEMASANGAN KATETER DENGAN KEJADIAN INFEKSI SALURAN KEMIH PADA PASIEN DI RUANG RAWAT INAP
}

\author{
Tiarnida Nababan \\ Fakultas Keperawatan dan Kebidanan \\ Universitas Prima Indonesia, Medan, Indonesia \\ Email: tiarnidan@yahoo.com
}

\begin{abstract}
Urinary tract infection (UTI) is a result of the development of microorganisms in the urinary tract, which in normal conditions do not contain bacteria, viruses, or other microorganisms. Urinary tract infections are also infections that occupy the second position that most often attacks the body after respiratory infections. The objective of the study was to identify the relationship between catheter placement and the incidence of urinary tract infections at Royal Prima hospital Medan. This is a correlation study (correlation study) on the patients suffering from urinary tract infections. The sampling technique used was a saturated sampling technique. Analysis research data using the Spearmen test. Based on the results of the study, it was found that the majority of catheter installation was in the category of good were $78 \%$, and in the category of not good $22 \%$, and $78 \%$ suffered from do not experience urinary tract infections, and $22 \%$ infection urinary tract. The results of the study of the Spearmen test showed that p-value $=0.00$. It was found that there was a relationship between catheter insertion and the incidence of urinary tract infections in the inpatient room. The local nurses are suggested to improve the aseptic technique of care performed when catheterization is performed so that the incidence of urinary tract infections due to catheter installation can be avoided.
\end{abstract}

\section{Keywords: Catheter Installation, Urinary Tract Infection (UTI), Hospitalization}

\section{PENDAHULUAN}

Pemasangan kateter urin merupakan suatu tindakan invasif dengan cara memasukkan selang ke dalam kandung kemih dan untuk membantu proses pengeluaran urin dalam tubuh (Mobalen, Tansar, \& Maryen, 2019). Kateterisasi uretra yaitu suatu metode primer dekompresi kandung kemih dan menjadi alat diagnostik pada keadaan retensi urin akut (Semaradana, 2014).

Infeksi saluran kemih terkait kateter tetap menjadi salah satu infeksi terkait perawatan kesehatan yang paling umum namun dapat dicegah dan sebagian besar terjadi pada pasien dengan kateter urin yang menetap (Chenoweth \& Saint, 2016). Infeksi saluran kemih (ISK) merupakan salah satu penyakit yang banyak terjadi dan disebabkan karena infeksi, selain infeksi saluran pernafasan. Penyakit ISK dilaporkan sebanyak 8,3 juta kasus per tahun dan lebih sering ditemukan pada wanita dari pada laki-laki (Darsono, Mahdiyah, \& Sari, 2016). Prevalensi ISK menjadi tinggi pada pasien sebanyak $80 \%$ yang memakai kateter dan 10\%-30\% pasien mengalami bakteriuria (Semaradana, 2014). 
Sementara itu penduduk Indonesia yang menderita Infeksi Saluran Kemih diperkirakan 222 juta jiwa, dan prevalensinya masih relatif cukup tinggi. Menurut Departemen Kesehatan RI, pasien dengan ISK sebanyak 90-100 kasus per 100.000 penduduk pertahun atau sekitar 180.000 kasus baru (Kemenkes, 2015). Penelitian Perdana (2017) menyatakan hubungan yang signifikan antara pelaksanaan perawatan kateter dengan kejadian infeksi saluran kemih. Hal ini dikarenakan tindakan perawatan dan pemasangan kateter belum dilakukan perawat dengan baik.

Penelitian Palimbunga, Rataq, dan Kaunang (2017) tentang faktor-faktor yang berhubungan dengan kejadian infeksi saluran kemih, ditemukan adanya hubungan antara kebiasaan menahan buang air kecil dengan kejadian infeksi saluran kemih. Jumlah pasien infeksi saluran kemih dan menjadi 10 penyakit tertinggi dari tahun 2014 hingga 2016 meningkat. Jumlah infeksi pada pasien rawat jalan menjadi 1.051 berada pada peringkat ke 10 pasien tahun 2016.

Penelitian Roby dan Pontianus, (2018) mengemukakan kejadian ISK diduga berhubungan dengan faktor risiko yaitu pemasangan kateterisasi perkemihan. Hal ini bertujuan untuk mengidentifikasi kejadian infeksi di saluran kemih pada pasien yang sudah terpasang katetersiasi di Ruang Rawat Inap RSU Imelda Pekerja Indonesia (IPI) Medan. Penelitian Pramudyaningrum, Huriah, dan Chayati (2019) menghasilkan penemuan bahwa bundle catheter education efektif untuk meningkatkan pengetahuan, sikap dan keterampilan perawat dalam pencegahan penyakit terkait pemasangan kateter urin.

Berdasarkan hasil survei yang dilakukan peneliti di instalasi rekam medik Rumah Sakit Umum dan hasil wawancara dengan pasien yang sedang terpasang kateter didapatkan ada yang mengalami infeksi saluran kemih karena kebiasaan menahan buang air kecil dan lamanya waktu pemasangan kateter. Penelitian ini bertujuan untuk mengetahui hubungan pemasangan kateter dengan kejadian infeksi saluran kemih.

\section{METODE}

Desain penelitian yang digunakan kuantitatif, dan jenis penelitian menggunakan studi korelasi (Correlation study) untuk mengetahui hubungan gejala satu dengan gejala yang lain.

Penelitian ini dilaksanakan di Rumah Sakit Umum Royal Prima Medan. Waktu pelaksanaan penelitian ini dilakukan pada bulan Mei 2018. 
Populasi adalah seluruh perawat yang bekerja di ruang rawat inap penyakit dalam RSU Royal Prima Medan lantai $9,10,11$ yang berjumlah 45 perawat. Pemilihan sampel dengan mengambil semua perawat di ruang rawat. Sampel penelitian menggunakan teknik sampling jenuh dengan mengambil semua populasi menjadi sampel sebanyak 45 orang perawat.

Penelitian ini mengambil data primer dari kuisioner dan lembar observasi, serta data sekunder berasal dari data rekam medik. Teknik pengumpulan data yang dilakukan dalam lembar observasi (pengamatan) sesuai dengan SOP pemasangan kateter di rumah sakit. Observasi dilakukan peneliti secara langsung. Kejadian infeksi dilihat setelah pemasangan kateter baru selama 7 hari penggunaan, dan diperhatikan tanda-tanda infeksi.
Analisa data yang dilakukan terdiri dari analisa univariat dan bivariat. Analisa univariat dilakukan untuk gambaran karakteristik responden, pemasangan kateter, dan kejadian infeksi. Data tersebut ditampilkan dalam bentuk tabel frekuensi. Analisa bivariat mengetahui adanya kedua variabel pemasangan kateter dan kejadian infeksi saluran kemih. Uji statistik yang digunakan uji Spearman dengan tingkat kemaknaan ( $\mathrm{p}$ value) yaitu 0,05 , apabila hasilnya didapat $<0,05$ maka berarti Ho ditolak atau Ha diterima.

\section{HASIL DAN PEMBAHASAN \\ Hasil}

\section{Karakteristik Responden}

Karakteristik responden berdasarkan jenis kelamin dan usia disajikan dalam Tabel di bawah ini:

Tabel 1. Distribusi Frekuensi dan Persentase Karakteristik Responden

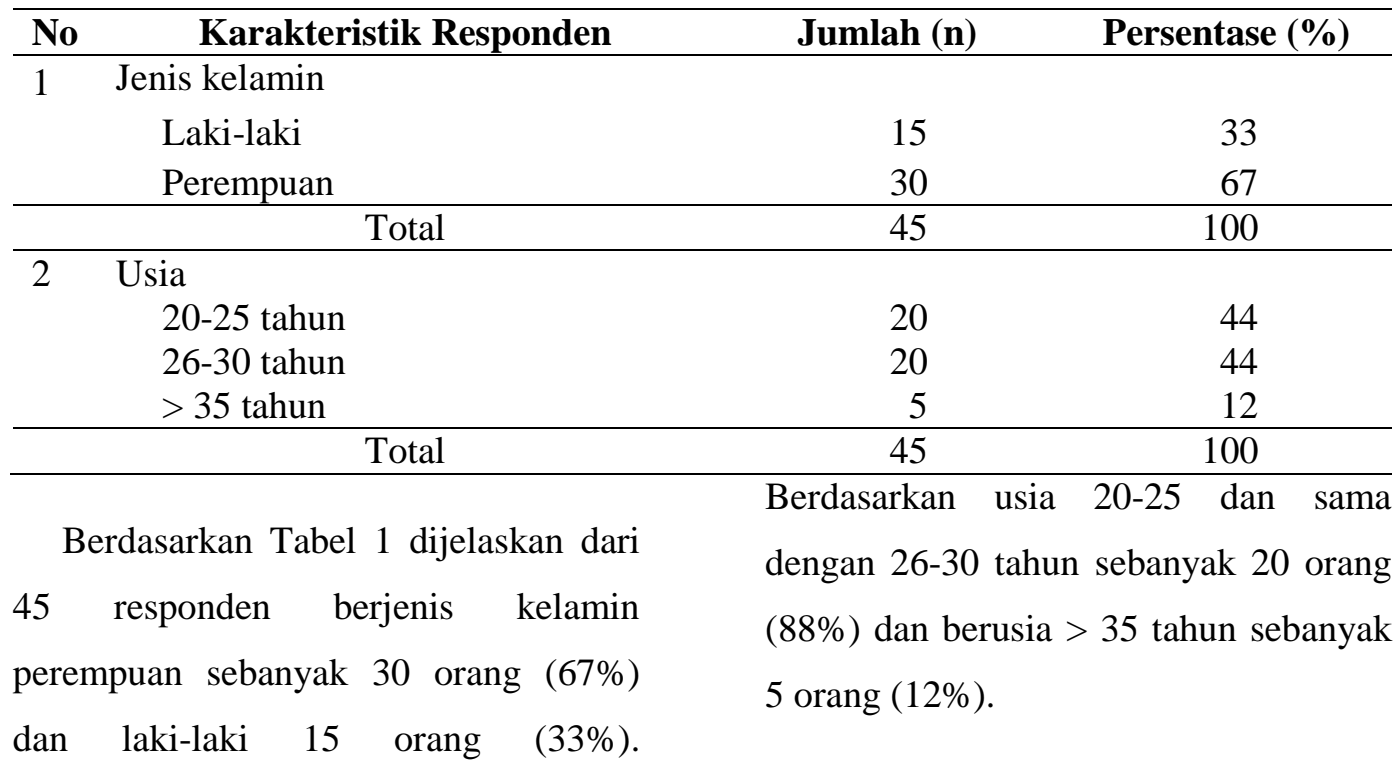




\section{Analisa Univariat}

Berdasarkan hubungan pemasangan

kateter dengan kejadian infeksi saluran kemih, dapat terlihat pada tabel sebagai berikut:

Tabel 2. Distribusi Frekuensi Pemasangan Kateter

\begin{tabular}{clcc}
\hline No & \multicolumn{1}{c}{ Kategori } & Jumlah & Persentase (\%) \\
\hline 1 & Baik (Sesuai SOP) & 35 & 78 \\
2 & Kurang Baik (Tidak Sesuai SOP) & 10 & 22 \\
\hline \multicolumn{2}{c}{ Total } & 45 & 100 \\
\hline
\end{tabular}

Berdasarkan Tabel 2 telah sebanyak 35 orang (78\%), dan minoritas ditunjukkan bahwa mayoritas pemasangan kateter kurang baik (tidak pemasangan kateter baik (sesuai SOP) sesuai SOP) sebanyak 10 orang (22\%).

Tabel 3. Distribusi Frekuensi Infeksi Saluran Kemih

\begin{tabular}{cccc}
\hline No & Kategori & Jumlah & Persentase (\%) \\
\hline 1 & Terjadi Infeksi & 5 & 11 \\
2 & Tidak Terjadi Infeksi & 40 & 89 \\
\hline & Total & 45 & 100 \\
\hline
\end{tabular}

Berdasarkan Tabel 3 di atas bahwa mayoritas perawat yang menyebabkan tidak terjadi infeksi saluran kemih sebanyak 40 orang $(89 \%)$ dan minoritas terjadi infeksi 5 orang (11\%).

\section{Analisa Bivariat}

Analisa data bivariat yang digunakan untuk mengetahui hubungan antara variabel dan dapat dilihat sebagai berikut:

Tabel 4. Pemasangan Kateter dengan Kejadian Infeksi Saluran Kemih

\begin{tabular}{|c|c|c|c|c|c|c|c|}
\hline \multirow{3}{*}{$\begin{array}{c}\text { Pemasangan } \\
\text { Kateter }\end{array}$} & \multicolumn{4}{|c|}{ Infeksi Saluran Kemih } & \multirow{2}{*}{\multicolumn{2}{|c|}{ Jumlah }} & \multirow{3}{*}{ p Value } \\
\hline & \multicolumn{2}{|c|}{ Infeksi } & \multicolumn{2}{|c|}{ Tidak Infeksi } & & & \\
\hline & n & $\%$ & $\mathrm{n}$ & $\%$ & $\mathbf{N}$ & $\%$ & \\
\hline Baik & 0 & 0 & 35 & 78 & 35 & 22 & \\
\hline Tidak Baik & 5 & 11 & 5 & 11 & 10 & 78 & 0,00 \\
\hline Total & 5 & 11 & 40 & 89 & 45 & 100 & \\
\hline
\end{tabular}

Berdasarkan Tabel 4 pemasangan kateter baik sebanyak 35 orang (22\%) dengan infeksi saluran kemih tidak ada dan tidak infeksi sebanyak 35 orang (22\%). Berdasarkan pemasangan kateter tidak baik berjumlah 10 orang (78\%) dengan infeksi saluran kemih 5 orang (11\%) dari tidak ada infeksi sebanyak 5 orang (11\%). Hasil uji Spearman nilai signifikan $\mathrm{p}$ value sebesar 0,00 hal ini berarti $<0,05$ maka Ho ditolak, artinya bahwa ada hubungan pemasangan kateter dengan kejadian infeksi saluran kemih. 


\section{Pembahasan}

\section{Analisa Univariat}

\section{Pemasangan Kateter}

Kateterisasi kandung kemih merupakan suatu tindakan memasukkan selang lateks atau plastik ke kandung kemih melalui uretra. Kateter menjadi saluran aliran urine kontinu pada klien yang tidak mampu menahan dan mengendalikan miksi atau pada penderita obstruksi.

Berdasarkan hasil dari penelitian di ruang rawat inap lantai 9, 10, 11 Rumah Sakit Umum dapat diketahui bahwa dari 45 orang responden mayoritas memberikan perawatan baik 35 orang (78\%) dan minoritas baik sebanyak 10 orang $(22 \%)$.

Menurut Perry, Potter, dan Ostendorf, (2014) pemasangan kateter yang baik itu yang pertama-tama mempersiapkan pasien kemudian baru kita melengkapi alat-alat yang dibutuhkan dalam pemasangan kateter seperti folly kateter, urin bag steril, pinset anatomi, sarung tangan steril, duk steril, kapas sublimat dalam kom tertutup, kassa steril, jelly, perlak dan pengalas, cairan aquades atau $\mathrm{NaCl}$ $0,9 \%$, nierbeken, korentang, plester, dan gunting verband,. Setelah alat-alat sudah dilengkapi maka kita melakukan cuci tangan dengan tujuan untuk mengurangi resiko trasnmisi mikroorganisme.
Menurut asumsi peneliti menunjukkan dari hasil observasi peneliti, responden minoritas tidak melakukan cuci tangan pada awal melakukan tindakan maupun pada akhir pelaksanaan tindakan pemasangan kateter dan kurang menjaga kesterilisasi alat dan perlengkapan alat yang kurang lengkap. Minoritas responden tidak memakai handscoon pada saat melakukan tindakan sehingga memudahkan mikroorganisme mudah masuk baik melalui alat atau secara kontak langsung.

Hasil penelitian Sari dan Satyabakti (2015) menunjukkan bahwa berdasarkan lama waktu pemasangan kateter urin sebesar $\mathrm{RD}=0,52$ adanya perbedaan risiko infeksi nosokomial saluran kemih artinya apabila dilakukan setiap 7 hari penggantian kateter pada pasien, maka dapat mencegah sebanyak $73,53 \%$ kejadian ISK, dan data frekuensi kateterisasi urin sebesar $\mathrm{RD}=0,44$ artinya apabila dilakukan metode pengurangan kateterisasi urin sampai 1 kali, maka dapat menghindari sebanyak 55,94\% kejadian ISK.

\section{Infeksi Saluran Kemih}

Berdasarkan hasil dari kejadian ISK dapat diketahui bahwa dari 45 orang perawat, mayoritas tidak menyebabkan infeksi saluran kemih kepada pasien 
sebanyak 40 orang (89\%) dan minoritas terjadi infeksi 5 orang (11\%).

Faktor-faktor yang mempengaruhi angka kejadian infeksi saluran kemih antara lain berasal bakteri (uropatogen) pseudomonas aeruginosa E.coli (UPEC) yang bermuatan $P$ fimbriae, dan dapat dipengaruhi faktor penyakit seperti penyakit HIV, DM tipe 2, inkontinensia urin serta faktor lain seperti multi-drug resisten, penggunaan popok anak yang lama, kurang menjaga kebiasan mencuci tangan, dan anak yang belum di sirkumsisi (Irawan \& Mulyana, 2018). Jenis kelamin, batu saluran kemih, dan diabetes melitus juga merupakan faktor risiko terhadap kejadian ISK (Hermiyanty, 2016).

Menurut penelitian Suryarinilsih dan Aulia (2018), menjelaskan bahwa penggunaan kateter yang lama terpasang pada pasien memiliki hubungan dengan terjadinya infeksi saluran kemih. Penelitian Putri, Armiyati, \& Supriyono (2015), menyatakan kejadian infeksi saluran kemih (ISK) pada pasien dengan kateter menetap disebabkan oleh penggunaan kateter lebih dari 3 hari.

Menurut asumsi peneliti tingginya resiko infeksi saluran kemih apabila perawat tidak melakukan prosedur aseptik saat kateterisasi. Perawat kurang menjaga kebersihan, sehingga mikroorganisme dengan mudah masuk melalui saluran kandung kemih.
Kemudian mikroba patogen tersebut berkembang biak dan menyebabkan gangguan fungsi organ yang semakin luas.

\section{Analisa Bivariat}

Berdasarkan uji Spearman menunjukkan bahwa nilai $\mathrm{p}$-value $=0,00$ artinya ada hubungan pemasangan kateter dengan kejadian infeksi saluran kemih di ruang rawat inap. Menurut peneliti hal ini disebabkan karena perawatan dan pemasangan kateter yang belum optimal dan tidak sesuai SOP, baik di alat maupun petugas medisnya sehingga meningkatkan resiko terjadinya infeksi.

Menurut penelitian Putri, Armiyati, dan Supriyono (2015), secara umum faktor risiko ini dibagi menjadi 2 faktor.. Faktor yang tidak dapat diubah antara lain usia, jenis kelamin, penyakit, virulensi kuman dan faktor risiko yang dapat diubah seperti lama penggunaan kateter, prosedur pemasangan kateter, perawatan kateter, ukuran dan tipe kateter, personal hygiene dan asupan cairan.

Penelitian Selano, Panjaitan, dan Raharjo, (2019) didapatkan adanya hubungan antara kepatuhan perawat dalam menjalankan SOP perawatan kateter dengan angka kejadian ISK. Penelitian ini menjelaskan bahwa apabila perawatan kateter tidak dilaksanakan dengan baik dan benar 
maka dapat menyebabkan terjadinya infeksi saluran kemih (ISK). Penelitian Storme, Tirán Saucedo, Garcia-Mora, Dehesa-Dávila, dan Naber (2019) menjelaskan bahwa memahami faktorfaktor risiko spesifik individu dan populasi yang terkait dengan infeksi saluran kemih berulang (ISK) dapat membantu dokter menyesuaikan strategi profilaksis.

Strategi yang ditargetkan untuk pencegahan termasuk membatasi penggunaan kateter urin; sistem pengingat dokter, protokol penghentian yang diprakarsai perawat, dan perintah berhenti otomatis telah berhasil menurunkan durasi kateter. Jika perlu dilakukan kateterisasi, praktik aseptik yang tepat untuk pemasangan dan pemeliharaan kateter dan sistem pengumpulan kateter tertutup sangat penting untuk mencegah infeksi (Chenoweth \& Saint, 2016).

\section{KESIMPULAN DAN SARAN}

\section{Kesimpulan}

Karakteristik responden berdasarkan data jenis kelamin dan usia menunjukkan bahwa mayoritas berjenis kelamin perempuan, dan berdasarkan usia mayoritas berusia 20-25 tahun dan 26-30 tahun.

Pemasangan kateter mayoritas pemasangan kateter baik (sesuai SOP), dan Infeksi saluran kemih mayoritas yang perawat tidak menyebabkan infeksi saluran kemih.

Hasil penelitian ini didapatkan ada hubungan pemasangan kateter dengan kejadian infeksi saluran kemih.

\section{Saran}

\section{Bagi Responden}

Bagi responden diharapkan dapat menambah pengetahuan dan keterampilan dalam praktek keperawatan kateterisasi sehingga dapat mencegah kesalahan pemasangan kateter yang dapat menimbulkan resiko infeksi, serta dapat mengaplikasikannya dalam praktek keperawatan sesuai dengan SOP.

\section{Bagi Tempat Penelitian}

Diharapkan tempat penelitian khususnya manajemen keperawatan dapat memperhatikan dan mengawasi prosedur pemasangan kateter dengan baik sehingga tidak ada kejadian infeksi saluran kemih.

\section{Bagi Peneliti Selanjutnya}

Diharapkan dijadikan referensi tentang penelitian terkait faktor-faktor yang mempengaruhi pemasangan kateter dengan kejadian infeksi saluran kemih.

\section{DAFTAR PUSTAKA}

Chenoweth, C. E., \& Saint, S. (2016). Urinary Tract Infections. Infectious Disease Clinics of North America. https://doi.org/10.1016/j.idc.2016.07. 007

Darsono, P. V., Mahdiyah, D., \& Sari, M. (2016). Gambaran karakteristik 
ibu hamil yang mengalami infeksi saluran kemih (ISK) di Wilayah Kerja Puskesmas Pekauman Banjarmasin. Dinamika Kesehatan Jurnal Kebidanan dan Keperawatan.

Hermiyanty, H. (2016). Faktor risiko infeksi saluran kemih di bagian rawat inap RSU Mokopido Tolitoli tahun 2012. Healthy Tadulako.

Irawan, E., \& Mulyana, H. (2018). Faktor-faktor penyebab infeksi saluran kemih (ISK). Prosiding Seminar Nasional dan Diseminasi Penelitian Kesehatadn.

Kemenkes. (2015). Kementerian Kesehatan Republik Indonesia 2015. In Profil Kesehatan Indonesia 2014.

Mobalen, O., Tansar, T., \& Maryen, Y. (2019). Perbedaan pemasangan kateter dengan menggunakan jelly yang dimasukkan uretra dan jellyyang dioleskan di kateter terhadap tingkat nyeri pasien di RSUD Sele Be Solu Kota Sorong. Nursing Arts. https://doi.org/10.36741/jna.v13i2.90

Palimbunga T M, Rataq B T, K. W. P. J. (2017). Faktor-faktor yang berhubungan dengan Kejadian Diabetes Melitus Tipe 2 di RSU GMIM Pancaran Kasih Manado. FKM Unsrat Manado.

Perdana, M. dkk. (2017). Hubungan pelaksanaan perawatan indwelling kateter dengan kejadian infeksi saluran kemih. Jurnal Keperawatan Klinis dan Komunitas.

Perry, A. G., Potter, P. A., \& Ostendorf, W. R. (2014). Clinical Nursing Skills \& Techniques. In Elsevier.

Pramudyaningrum, R., Huriah, T., \& Chayati, N. (2019). Pencegahan infeksi saluran kemih pada pemasangan kateter dengan teknik bundle catheter education. Jurnal Kebidanan Dan Keperawatan Aisyiyah. https://doi.org/10.31101/jkk.1033

Putri, R. A., Armiyati, Y., \& Supriyono, M. (2015). Faktor - faktor yang berpengaruh terhadap kejadian infeksi saluran kemih pada pasien rawat inap. In Karya Ilmiah.
Roby, G., \& Pontianus, F. (2018). Analisis kateterisasi terhadap kejadian infeksi di saluran kemih pada pasien ruang rawat inap rsu Imelda Pekerja Indonesia (IPI) Medan tahun 2017 1. Jurnal Ilmiah Farmasi Imelda.

Sari.E.W.P., Satyabakti, P. (2015). Perbedaan risiko infeksi nosokomial saluran kemih berdasarkan kateterisasi urin, umur, dan diabetes melitus. Departemen Epidemiologi Fakultas Kesehatan Masyarakat Universitas Airlangga.

Selano, M. K., Panjaitan, R. N., \& Raharjo, S. B. (2019). Hubungan kepatuhan perawat melaksanakan standar prosedur operasional perawatan kateter menetap dengan angka kejadian infeksi saluran kemih. Jurnal Smart Keperawatan. https://doi.org/10.34310/jskp.v6i1.21 6

Semaradana, W. G. (2014). Infeksi saluran kemih akibat pemasangan kateter - diagnosis dan penatalaksanaan. Continuing Professional Development IAI.

Storme, O., Tirán Saucedo, J., GarciaMora, A., Dehesa-Dávila, M., \& Naber, K. G. (2019). Risk factors and predisposing conditions for urinary tract infection. Therapeutic Advances in Urology. https://doi.org/10.1177/ 1756287218814382

Suryarinilsih, Y., -, D., \& Aulia, M. (2018). Lamanya Penggunaan Kateter dengan Kejadian Infeksi Saluran Kemih pada Pasien Terpasang Kateter. Jurnal Persatuan Perawat Nasional Indonesia (JPPNI).https://doi.org/10.32419/jpp ni.v2i3.92 